\title{
RANCANG BANGUN SISTEM PENDUKUNG KEPUTUSAN PEMBAGIAN BEBAN KERJA DOSEN (BKD) BERBASIS LOGIKA FUZZY
}

\author{
Syamsul $^{1}$ \\ ${ }^{1}$ Dosen Jurusan Teknik Elektro Politeknik Negeri Lhokseumawe \\ Email: syamsul0466@gmail.com
}

\begin{abstract}
ABSTRAK
Beban Kerja Dosen (BKD) meliputi beban dalam bidang pendidikan dan pengajaran, bidang penelitian, bidang pengabdian pada masyarakat, dan kegiatan-kegiatan penunjang. Pemberian beban kerja tersebut mengacu pada Undang-undang tentang Guru dan Dosen, Peraturan Pemerintah tentang Dosen dan Peraturan Menteri Pendidikan tentang Sertifikasi Dosen. Seorang Dosen memiliki kewajiban minimal dan maksimal dalam mengemban tugas pokoknya. Berdasarkan ketentuan undang-undang dan peraturan-peraturan tersebut pemberian beban kerja harus sesuai dan memenuhi agar hak-haknya sebagai dosen Profesional tidak diberhentikan. Selama ini pembagian dan pengaturan beban kerja terutama pada jurusan Teknik Elektro Politeknik Negeri Lhokseumawe masih menggunakan cara konvensional oleh karena itu diperlukan suatu sistem agar pembagian beban kerja dosen dapat dilakukan secara cepat, tepat, dan juga sesuai dengan, kebutuhan, kemampuan dan keahlian dosen tersebut. Sehingga setiap dosen dapat bekerja sesuai dengan kewajibannya, untuk mendapatkan hak-haknya. Tujuan jangka panjang dengan sistem ini adalah proses pembelajaran akan meningkatkan kualitas peserta didik (mahasiswa) yang pada giliranya akan menghasilkan lulusan yang berkualitas juga. Sedangkan target dari penelitian ini adalah mempermudah pembagian beban kerja dosen terutama pembagian beban kerja mengajar dan pembagian kerja kegiatan penunjang agar sesuai dengan bidang keahlian dosen berbasis komputer. Metode penelitian yang digunakan agar tujuan dan target yang diinginkan tercapai adalah: mendesain sistem berbasis komputer, dimana langkah-langkah perancangan dimulai dari perancangan logika Fuzzy dengan variabel masukan kegiatan penelitian dan kegiatan pengabdian pada masyarakat, kegiatan penunjang, dan kegiatan utama lainnya, dan outputnya berupa beban mengajar dosen dalam sks yang direkomendasikan. Untuk mempermudah pemakai (user) dalam apalikasinya diperlukan perancangan form interface yaitu berhubungan dengan pemasukan data inputan dan yang terakhir adalah perancangan laporan (report), yaitu hasil dari seluruh proses sistem yang akan mengeluarkan datadata baik beban mengajar dan beban kerja lainnya. Keluaran dari perangkat lunak yang dibuat adalah jumlah beban mengajar minimal dan maksimal yang direkomendasikan sudah sesuai dengan rancangan.
\end{abstract}

\section{Kata-kata kunci: Dosen, BKD (beban kerja dosen), Logika Fuzzy}

\section{PENDAHULUAN}

Dosen merupakan salah satu unsur pertama dalam civitas akademika dalam sebuah perguruan tinggi (PT). Secara umum dosen tergolong sebagai pendidik yang professional seperti yang tercantum dalam UU R.I. Nomor 20 tahun 2003 tentang Sistem Pendidikan Nasional, dalam pasal 39 (2) mengatakan bahwa "Pendidik merupakan tenaga profesional yang bertugas merencanakan dan melaksanakan proses pembelajaran, menilai hasil pembelajaran, melakukan pembimbingan dan pelatihan, serta melakukan penelitian dan pengabdian kepada masyarakat, terutama bagi pendidik pada perguruan tinggi"'[3]. Kewajiban sebagai dosen dituangkan dalam pasal 40 ayat (2) yaitu:

1. Menciptakan suasana pendidikan yang bermakna, menyenangkan, kreatif, dinamis dan dialogis.

2. Mempunyai komitmen secara profesional untuk meningkatkan mutu pendidikan.

3. Memberi teladan dan menjaga nama baik lembaga, profesi, dan kedudukan sesuai dengan kepercayaan yang diberikan kepadanya.

Beban kerja dosen (BKD) terdiri dari 4 unsur yaitu unsur pendidikan dan pengajaran, unsur penelitian, unsur pengabdian pada masyarakat dan kegiatan penunjang. Ada 3 unsur yang tidak boleh ditinggalkan oleh seorang dosen yaitu unsur pendidikan dan pengajaran, unsur penelitian dan unsur pengabdian pada masyarakat. BKD ini merupakan kewajiban setiap dosen terutama sekali kepada dosen yang telah tersertifikasi.

Selain itu, beban kerja dosen ini memiliki ketentuan batas mnimal dan maksimal tergantung kepada kedudukan dan jabatan dosen tersebut pada lembaga pendidikan tinggi. Seorang dosen biasa (DS) memiliki kewajiban penuh dalam beban kerjanya yaitu 12 sks sampai dengan 16 sks dari keempat unsur di atas. Dengan ketentuan 3 unsur utama tidak boleh kosong. Dan juga sks dari dua unsur utama yaitu pendidikan dan pengajaran minimal 9 sks, sedangkan dari unsur pengabdian pada masyarakat dan kegiatan penunjang minimal 3 sks. Sedangkan dosen dengan tugas tambahan (DT) hanya dibebani kewajiban dalam unsur pendidikan dan pengajaran dengan beban minimal 4 sks.

Politeknik Negeri Lhokseumawe, dalam hal ini sebagai institusi pendidikan tinggi yang melaksanakan program pendidikan jalur vokasi, yaitu program pendidikan yang menyiapkan lulusanya memiliki pekerjaan dengan keahlian terapan. 
Permasalahan pada penelitian ini adalah beban kerja dosen (BKD) terutama untuk pembagian beban mengajar pada setiap dosen, tidak didasarkan kepada kebutuhan dan kewajiban dari dosen tersebut. Pembagian beban sering kali masih menumpuk pada dosen yang dianggap rajin saja, atau pembagiannya dibuat rata-rata tanpa memperhatikan jabatan dari dosen tersebut (DT atau DS). Di samping itu pembagian beban mengajar, belum memperhatikan latar belaknag pendidikan dan mata kuliah yang diampu sebelumnya. Sering seorang dosen berganti mata kuliah yang diampunya, padahal mata kuliah tersebut diluar bidang keahlianya, sedangkan dosen yang memiliki bidang keahlian yang sama masih memungkinkan untuk mengampu mata kuliah tersebut. Permasalahan-permasalahan tersebut akan menimbulkan pengaruh pada proses pembelajaran, seperti beban kerja dosen terlalu banyak (menumpuk), dan ada beban dosen yang terlalu sedikit. Sehingga kualitas pembelajaran juga tidak berubah sebelum dan setelah adanya sertifikasi dosen.

Dari permasalahan-permasalahan tersebut di atas, maka rumusan masalahnya adalah mendesain suatu suatu sistem yang berbasis komputer untuk membagi beban kerja dosen (BKD) terutama beban mengajar dapat menghasilkan output yang cepat dan tepat berdasarkan parameter-parameter seperti kedudukan dosen tersebut (DS atau DT), tidak memperhitungkan tugas tambahan Profesor, kebutuhan dosen akan mata kuliah yang akan diampu, kelompok bidang keahlian, program studi, jumlah dosen yang ada saat ini, dan kegiatan pada unsur lain selain pengajaran. Sedangkan metode yang akan dipergunakan untuk menyelasaikan masalah tersebut adalah logika Fuzzy, objek penelitiannya adalah pada Jurusan Teknik Elektro Politeknik Negeri Lhoskeumawe dan program aplikasi menggunakan Microsoft access 2007.

Penelitian ini bertujuan untuk membantu jurusan dalam hal ini program studi dalam membagi beban kerja dosen terutama beban mengajar, yaitu dengan membuat suatu perangkat lunak (software) yang aplikatif dan mudah digunakan. Perangkat lunak ini menggunakan program aplikasi Microsoft access 2007. Dengan adanya perangkat lunak ini, beban mengajar dosen dapat dihasilkan dengan cepat dan sesuai dengan keperluannya. Perangkat lunak yang dibangun ini juga bertujuan untuk mengantisipasi adanya kekurangan beban kerja dosen, sehingga keberlanjutan sertifikasi dosen pada jurusan (dalam hal ini Jurusan Teknik Elektro) tidak menimbulkan masalah.

Manfaat yang dapat dihasilkan dari penelitian ini adalah dapat digunakan sebagai alat bantu berupa perangkat lunak (software) dalam mengambil keputusan untuk membagi beban kerja dosen (yaitu beban mengajar) agar beban tersebut tidak melanggar undang-undang dan peraturan-peraturan yang berhubungan dengan sertifikasi dosen (serdos).
Perangkat lunak yang dihasilkan dapat dijadikan alat bantu agar beban yang diberikan kepada dosen tidak subyektif, tetapi pembagian beban kerja sesuai dengan kebutuhan dan kemampuan dari seorang dosen.

\section{TINJAUAN PUSTAKA}

Penelitian yang berhubungan dengan beban kerja dosen sebelumnya sudah ada yang melakukan yaitu sistem pendukung keputusan dosen berprestasi yang didalamnya mencakup proses evaluasi Beban Kerja Dosen (BKD) dan pemilihan dosen berprestasi dengan menggunakan metode Promethee [1], dimana inti pembahasan pada penelitian ini adalah memanfaat BKD yang sudah dilakukan oleh dosen kemudian dievaluasi oleh tim untuk menentukan dosen berprestasi. Pada penelitian ini tidak membahas pembagian beban kerja dosen dan juga tidak menjelaskan kebutuhan beban kerja dosen untuk memenuhi kewajiban minimal dan maksimal seorang dosen terutama setelah sertifikasi dosen diperoleh.

Sistem Pendukung Pengambilan Keputusan Penjadwalan Kuliah Berdasarkan Preferensi Kesediaan Waktu Dosen Untuk Mengajar (Studi kasus pada STIE SBI Yogyakarta)[8], membahas tentang penjadwalan kuliah namun tidak menghubungkannya dengan batasan minimal dan maksimal dari beban mengajar yang memenuhi undang-undang. Dalam penelitian ini fokus penelitian hanya pada jadwal mengajar saja agar sesuai keinginan dosen, dan sistem yang dibangun bertujuan untuk mempermudah Jurusan/Program studi dalam menjadwal kuliah saja.

\subsection{Sistem Pendukung Keputusan (SPK)}

Sistem pendukung keputusan adalah sebuah sistem informasi berbasis komputer yang interaktif, fleksibel dan mudah beradaptasi, didesain secara khusus untuk membantu masalah managemen yang bersifat tidak terstruktur untuk memperbaiki pengambilan keputusan[7].

Secara garis besar DSS dibangun oleh tiga komponen besar: 1) Database; 2) Model Base; dan 3) Software System. Sistem database berisi kumpulan dari semua data bisnis yang dimiliki perusahaan, baik yang berasal dari transaksi sehari-hari, maupun data dasar (master file). Untuk keperluan DSS, diperlukan data yang relevan dengan permasalahan yang hendak dipecahkan melalui simulasi. Komponen kedua adalah Model Base atau suatu model yang merepresentasikan permasalahan ke dalam format kuantitatif (model matematika sebagai contohnya) sebagai dasar simulasi atau pengambilan keputusan, termasuk di dalamnya tujuan dari permasalahan (obyektif), komponen-komponen terkait, batasanbatasan yang ada (constraints), dan hal-hal terkait lainnya.

Kedua komponen tersebut untuk selanjutnya disatukan dalam komponen ketiga (software system), setelah sebelumnya direpresentasikan dalam bentuk 
model yang "dimengerti" komputer . Contohnya adalah penggunaan teknik RDBMS (Relational Database Management System), OODBMS (Object Oriented Database Management System) untuk memodelkan struktur data. Sedangkan MBMS (Model Base Management System) dipergunakan untuk mere-presentasikan masalah yang ingin dicari pemecahannya. Entiti lain yang terdapat pada produk DSS baru adalah DGMS (Dialog Generation and Management System), yang merupakan suatu sistem untuk memungkinkan terjadinya "dialog" interaktif antara komputer dan manusia (user) sebagai pengambil keputusan.

\subsubsection{Tahap-tahap Sistem Pengambilan Keputusan}

Tahap-tahap yang harus dilalui dalam proses pengambilan keputusan sebagai berikut[4]:

a. Tahap Pemahaman (Inteligence Phace)

Tahap ini merupakan proses penelusuran dan pendeteksian dari lingkup problematika serta proses pengenalan masalah. Data masukan diperoleh, diproses dan diuji dalam rangka mengidentifikasikan masalah.

b. Tahap Perancangan (Design Phace)

Tahap ini merupakan proses pengembangan dan pencarian alternatif tindakan/solusi yang dapat diambil. tersebut merupakan representasi kejadian nyata yang disederhanakan, sehingga diperlukan proses validasi dan vertifikasi untuk mengetahui keakuratan model dalam meneliti masalah yang ada.

c. Tahap Pemilihan (Choice Phace)

Tahap ini dilakukan pemilihan terhadap diantaraberbagai alternatif solusi yang dimunculkan pada tahap perencanaan agar ditentukan/dengan memperhatikan kriteriakriteria berdasarkan tujuan yang akan dicapai.

d. Tahap Impelementasi (Implementation Phace) Tahap ini dilakukan penerapan terhadap rancangan sistem yang telah dibuat pada tahap perancanagan serta pelaksanaan alternatif tindakan yang telah dipilih pada tahap pemilihan.

\subsubsection{Komponen Sistem Pendukung Keputusan}

Sistem pendukung keputusan terdiri dari 3 komponen utama atau subsistem yaitu[2]:

a. Subsistem Data (Database)

Susbsistem data merupakan komponen sistem pendukung keputusan penyedia data bagi sistem. Data yang dimaksud disimpan dalam suatu pangkalan data (database) yang diorganisasikan oleh suatu sistem yang disebut dengan sistem manajemen pangkalan data (Data Base Management System $=D B M S)$. Melalui DBMS inilah data dapat diambil dan dievakuasi dengan cepat. Pangkalan data dalam sistem pendukung keputusan berasal dari dua sumber yaitu sumber internal (dari dalam perusahaan) dan sumber eksternal (dari luar perusahaan). Data eksternal ini sangat berguna bagi manajemen dalam mengambil keputusan. b. Subsistem model (Model Base)

Keunikan sistem pendukung keputusan adalah kemampuan dalam mengintegrasikan data dengan model-model keputusan. Model adalah suatu peniruan dari alam nyata. Kendala yang sering dihadapi dalam merancang suatu model adalah bahwa model yang disusun ternyata tidak mampu mencerminkan seluruh variable alam nyata. Sehingga keputusan yang diambil didasarkan pada model tersebut menjadi tidak akurat dan tidak sesuai dengan kebutuhan. Oleh karena itu dalam menyimpan berbagai model pada system pangkalan model harus tetap dijaga fleksibelitasnya. Hal lain yang perlu diperhatikan adalah pada setiap model yang disimpan hendaknya ditambahkan rincian keterangan dan penjelasan yang komperherensif mengenai model yang dibuat, sehingga pengguna atau perancang:

1) Mampu membuat model yang baru dengan mudah dan cepat.

2) Mampu mengakses dan mengintegrasikan sub rutin model.

3) Mampu menghubungkan model dengan model lain melalui pangkalan data.

4) Mampu mengelola model base dengan fungsi manajemen yang analog dengan manajemen database.

5) Subsistem dialog (User Sistem Interface) Keunikan lain dari sistem pendukung keputusan adalah adanya fasilitas yang mampu mengintegrasikan sistem yang terpasang dengan pengguna secara interaktif. Fasilitas atau subsistem ini dikenal sebagai subsistem dialog, inilah sistem diartikulasikan dan diimplimentasikan sehingga pengguna atau pemakai dapat berkomunikasi dengan sistem yang dirancang.

\subsection{Fuzzy Logic}

Fuzzy merupakan representasi suatu pengetahuan yang dikonstruksikan dengan if-then rules. Karakteristik dari metode ini adalah[5][6][9]:

a. Pemecahan masalah dilakukan dengan menjelaskan sistem bukan lewat angka-angka, melainkan secara linguistik, atau variabelvariabel yang mengandung ketidakpastian/ ketidaktegasan.

b. Pemakaian IF-FHEN rules untuk menjelaskan kaitan antara satu variabel dengan yang lain.

c. Menjelaskan sistem memakai algoritma fuzzy Fuzzy merupakan salah satu metode yang memiliki kelebihan-kelebihan, diantaranya[5][6][9]:

a. Dapat mengekspresikan konsep yang sulit untuk dirumuskan, seperti misalnya "suhu ruangan yang nyaman".

b. Pemakaian membership-function memungkinkan fuzzy untuk melakukan observasi obyektif terhadap nilai-nilai yang subyektif. Selanjutnya membership-function ini dapat dikombinasikan 
untuk membuat pengungkapan konsep yang lebih jelas.

c. Penerapan logika dalam pengambilan keputusan, memberikan hasil yang lebih baik. Secara umum dalam sistem logika fuzzy terdapat empat buah elemen dasar, yaitu:

1. Basis kaidah (rule base), yang berisi aturanaturan secara linguistik yang bersumber dari para pakar;

2. Suatu mekanisme pengambilan keputusan (inference engine), yang memperagakan bagaimana para pakar mengambil suatu keputusan dengan menerapkan pengetahuan (knowledge);

3. Proses fuzzifikasi (fuzzification), yang mengubah besaran tegas (crisp) ke besaran fuzzy;

4. Proses defuzzifikasi (defuzzification), yang mengubah besaran fuzzy hasil dari inference engine, menjadi besaran tegas (crisp).

5. Pola masukan dihitung maju mulai dari layar masukan hingga layar keluaran menggunakan fungsi aktivasi yang ditentukan.

\subsection{Dosen dan Beban Kerja Dosen (BKD)}

Menurut Peraturan Pemerintah Nomor 37 Tahun 2009, Dosen adalah pendidik profesional dan ilmuwan dengan tugas utama mentransformasikan, mengembangkan dan menyebarluaskan ilmu pengetahuan, teknologi, dan seni melalui pendidikan, penelitian dan pengabdian kepada masyarakat[3]. Sedangkan Profesor atau Guru Besar adalah dosen dengan jabatan akademik tertinggi pada satuan pendidikan tinggi dan mempunyai kewajiban khusus menulis buku dan karya ilmiah serta menyebarkan luaskan gagasannya untuk mencerahkan masyarakat.

Tugas utama dosen tersebut adalah melaksanakan tridharma perguruan tinggi dengan beban kerja paling sedikit sepadan dengan 12 (dua belas) sks dan paling banyak 16 (enam belas) sks pada setiap semester sesuai dengan kualifikasi akademiknya dengan ketentuan sebagai berikut.

a. Tugas melakukan pendidikan dan penelitian paling sedikit sepadan dengan 9 (sembilan) sks yang dilaksanakan di perguruan tinggi yang bersangkutan.

b. Tugas melakukan pengabdian kepada masyarakat dapat dilaksanakan melalui kegiatan pengabdian kepada masyarakat yang diselenggarakan oleh perguruan tinggi yang bersangkutan atau melalui lembaga lain sesuai dengan peraturan perundang undangan.

c. Tugas penunjang tridarma perguruan tinggi dapat diperhitungkan sks nya sesuai dengan peraturan perundang undangan.

d. Tugas melakukan pengabdian kepada masyarakat dan tugas penunjang paling sedikit sepadan dengan 3 (tiga) SKS.

e. Tugas melaksanakan kewajiban khusus bagi profesor sekurang-kurangnya sepadan dengan 3 sks setiap tahun.

\section{METODE PENELITIAN}

Sistem yang digunakan untuk memberikan beban kerja yang meliputi beban dalm bidang pendidikan dan pengajaran, bidang penelitian, bidang pengabdian pada masyarakat dan kegiatan penunjang masih dilakukan secara manual.

Berdasarkan dengan undang-undang dan peraturan-peraturan yang telah ditetapkan seperti yang disebutkan dalam tinjauan pustaka sebelumnya, perlu dibangun suatu sistem yang lebih baik dalam hal pembagian beban mengajar dosen. Yaitu suatu sistem SPK berbasis komputer yang memberikan hasil berupa laporan tentang beban mengajar seorang dosen sehingga dengan memasukan variabel-variabel dan parameter-parameter masukan yang mempengaruhinya.

\subsection{Rancangan Penelitian} gambar 1

Diagram logic penelitian diperlihatkan pada Bagian Input; yang menjadi bagian dari sistem pembagian beban kerja dosen (BKD) adalah: Bidang yang termasuk dalam BKD yaitu: pendidikan dan pengajaran, penelitian, pengabdian pada masyarakat dan kegiatan penunjang.

Proses manual; yang dilakukan selama ini menggunakan cara manual, yaitu hanya mengguanakan database yang ada pada jurusan Teknik Elektro. Database dosen untuk melihat dosen yang aktif setiap semester, database mata kuliah untuk melihat mata kuliah yang diajarkan pada semester ini, database kelas untuk melihat jumlah kelas yang ada pada setiap program studi dan database kurikulum yang ada pada semester saat ini. Database lainnya seperti database penelitian, pengabdian pada masyarakat, penunjang dan karya ilmiah belum ada dan dalam proses pembagian BKD tidak diperhitungkan.

Proses dengan SPK (Sistem Pendukung Keputusan); berbasis komputer; menggunakan aturan BKD database yang sudah ada dan yang belum ada menjadi parameter-parameter yang mempengaruhi pembagian beban kerja dosen. Dosen tidak harus mengajar dengan jumlah sks yang sama, tetapi didesain agar jumlah beban yang diembannya sebanding dengan beban yang dipersyaratkan sesuai dengan undangundang dan peraturan-peraturan. Sebagai contoh: Dosen yang berstatus DT (Dosen dengan tugas tambahan) tidak memerlukan banyak sks dari unsur lain selain mengajar. Jadi beban sks terutama penunjang diberikan pada dosen DS (Dosen biasa) yang tidak memiliki jabatan. SPK ini dapat dibangun menggunakan metode logika Fuzzy dengan pertimbangan variabel masukan pada sistem ini lebih dari satu, tetapi hasil yang diperoleh tetap valid karena adanya fungsi IF-THEN.

Hasil atau output; menggunakan cara manual beban kerja dosen (BKD) hanya mengeluarkan data beban mengajar tanpa perhitungan yang sesuai dengan 
kebutuhan dosen tersebut sehingga tidak dapat mengantisipasi kecukupan BKD yang dipersyaratkan. Database yng dihasilkan hanya berupa database dosen, database mata kuliah, program studi dan kurikulum saja.

Output dengan SPK; menggunakan aturan BKD yang dipersyaratkan oleh undang-undang dan peraturan-peraturan, database yang diperlukan seperti database dosen, penelitian, pengabdian pada

\begin{tabular}{|l|} 
BND (Beban Kerja \\
Dosen)
\end{tabular}

\section{Database yang ada pada Jurusan Teknik elektro}

- Database dosen

- Database kurikulum

- Database kelompok bidang keahlian

- Database mata kuliah

- Database kelas pada setiap program studi

Database yang belum ada pada Jurusan Teknik Elektro

- Database penelitian

- Database pengabdian pada masyarakat

- Database kegiatan penunjang

- Karya Ilmiah/ publikasi masyarakat, karya ilmiah/publikasi dan penunjang merupakan variabel-variabel yang menentukan beban yang akan diemban oleh seorang dosen. Dengan sistem ini, tidak akan terjadi adanya dosen yang kelebihan dan kekurangan beban kerja, sehingga keberlangsungan sertifikasi akan tetap terjaga. Database secara keseluruhan akan tersimpan dalam sistem aplikasi, secara secara keseluruhan data yang menyangkut untuk keperluan BKD akan terintegrasi.

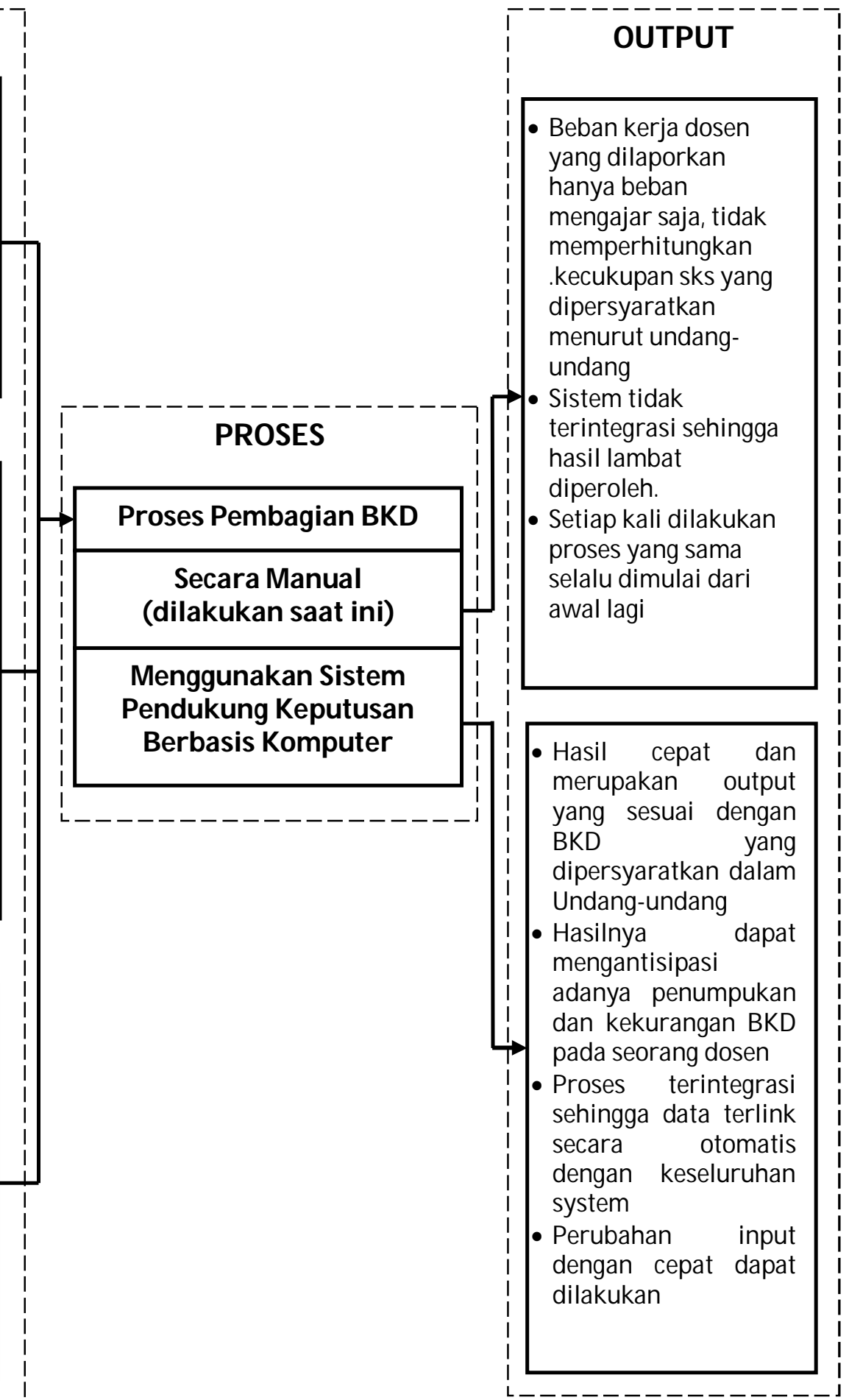

Gambar 1. Diagram logik dan kerangka berpikir penelitian 


\subsection{Desain sistem}

Perancangan aplikasi seperti yang diperlihatkan pada gambar 2 di bawah ini.

\begin{tabular}{|c|c|c|c|}
\hline $\begin{array}{c}\text { Perenca } \\
\text { naan } \\
\text { Logika } \\
\text { Fuzzy }\end{array}$ & $\rightarrow \begin{array}{c}\text { Perenca } \\
\text { naan } \\
\text { Databa } \\
\text { se }\end{array}$ & $\begin{array}{c}\text { Perenca } \\
\text { naan } \\
\text { Form } \\
\text { Interfa- } \\
\text { ce }\end{array}$ & $\begin{array}{c}\text { Perenca } \\
\text { naan } \\
\text { Laporan } \\
\text { Hasil } \\
\text { Proses }\end{array}$ \\
\hline
\end{tabular}

Gambar 2. Diagram perencanaan sistem

dari:

Dari gambar 2, perancangan sistem dimulai

\section{Perencanaan Logika Fuzzy}

Perencanaan Logika Fuzzy dilakukan untuk menentukan pembagian beban kerja dosen yaitu beban mengajar. Penggunaan logika Fuzzy dalam penelitian ini didasarkan pada beban mengajar dosen tidak sama untuk semua dosen tetapi merupakan ada batas minimal dan juga ada batas maksimal sesuai dengan ketentuan yang ada. Demikian juga dengan tingkat keaktifan dosen yaitu ada yang sedang melakukan penelitian seperti membuat penelitian mandiri, kelompok maupun menulis artikel dalam sebuah jurnal. Hal ini akan mempengaruhi penentuan jumlah beban mengajar yang akan diberikan pada dosen tersebut. Dosen dengan tugas tambahan dan dosen biasa juga tidak sama beban sks mengajarnya. Dari keadaan ini dipilih logika Fuzzy sebagai metode untuk menyelesaikannya. Varibel input sebagai masukan Fuzzy pada penelitian ini adalah: jumlah dosen aktif, jumlah penelitaian yang dilakukan (dalam bentuk sks), pengabdian pada masyarakat yang sedang dilakukan dan kegiatan penunjang. Sedangkan output fuzzy berupa beban mengajar dalam satuan sks. Pada langkah ini proses yang dilakukan adalah menentukan fungsi keanggotaan dari masing-masing variabel dengan memberi range nilai 0 sampai dengan 1.

\section{Perencanaan Database}

Perencanaan database adalah tahap selanjutnya dari sistem yang akan dibangun. Pada tahap ini database yang dikelola adalah database dosen yang ada pada Jurusan Teknik Elektro yang dibagi dalam kelompok dosen dalam kelompok bidang keahlian, database untuk mata kuliah yang juga dikelompokan dalam kelompok bidang. Perancangan database untuk aplikasi dibangun dengan menggunakan Physical Data Model Aplikasi, untuk menentukan relasi dari setiap database yang dibangun.

\section{Perencanaan Form Interface}

Perencanaan form interface adalah untuk memudahkan pengguna (user) dalam menginputkan data sebagai masukan dan proses perhitungannya sehingga diperoleh output sebagai hasil. Dengan menggunakan program aplikasi yang sudah umum digunakan yaitu Microsoft access, perencanaan form interface akan lebih mempermudah pengguna. Pada penelitian ini form interface akan menampilkan tampilan depan aplikasi, form-form isian yang dapat di-delete, ditambahkan, disimpan, form untuk perhitungan yaitu menentukan kesesuaian hasil yang diinginkan dan untuk keluar dari aplikasi.

\section{Perencanaan Laporan Hasil Proses}

Perencanaan laporan hasil berupa laporan yang dipergunakan oleh jurusan dan program studi untuk menyusun jadwal perkuliahan atau perencanaan lainnya seperti memperkirakan kebutuhan dosen dan studi lanjut dosen serta penambahan jumlah mahasiswa dalam hal pada jurusan Teknik Elektro.

\section{HASIL DAN PEMBAHASAN}

\subsection{Identifikasi Variabel Input}

Pada penelitian ini, variabel input yang dijadikan sebagai input Fuzzy adalah penelitian dan pengabdian pada masyarakat dan kegiatan penunjang. Masing-masing variabel input dan output seperti yang diperlihatkan pada gambar 3 .

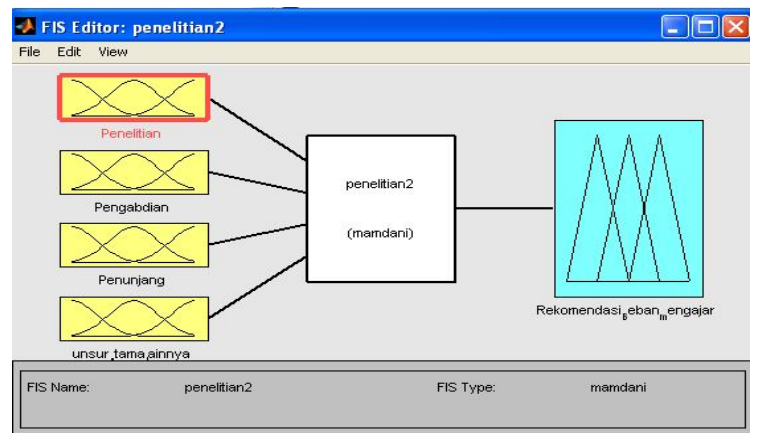

Gambar 3. Fuzzy input sistem yang digunakan pada penelitian

Dari gambar 3, dapat dijelaskan untuk masingmasing variabel input sebagai berikut:

a). Kegiatan penelitian merupakan kegiatan wajib yang tidak boleh kosong, sks yang diperoleh dapat mempengaruhi beban mengajar yang diberikan kepada seorang dosen. Untuk kegiatan penelitian menggunakan fungsi keanggotaan segitiga, seperti yang diperlihatkan pada gambar 4 .

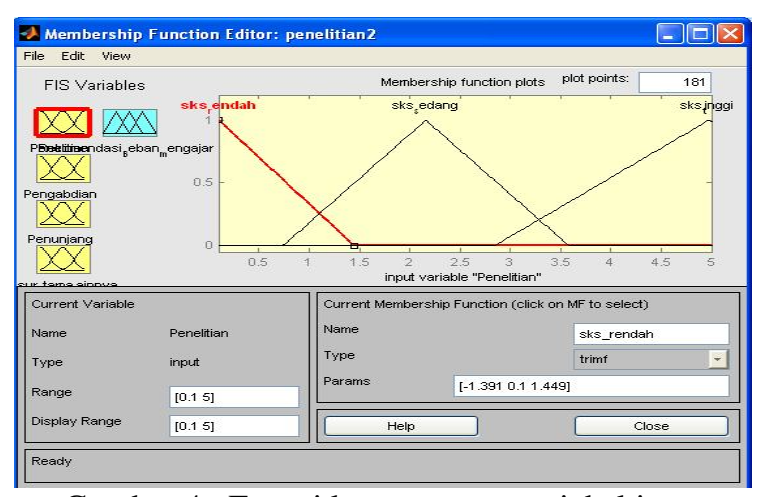

Gambar 4. Fungsi keanggotaan variabel input kegiatan penelitian

b) Kegiatan pengabdian pada masyarakat merupakan kegiatan wajib yang tidak boleh kosong, sks yang diperoleh dapat mempengaruhi beban mengajar yang diberikan kepada seorang dosen. Untuk kegiatan 
pengabdian pada masyarakat menggunakan fungsi keanggotaan segitiga, seperti pada gambar 5 .

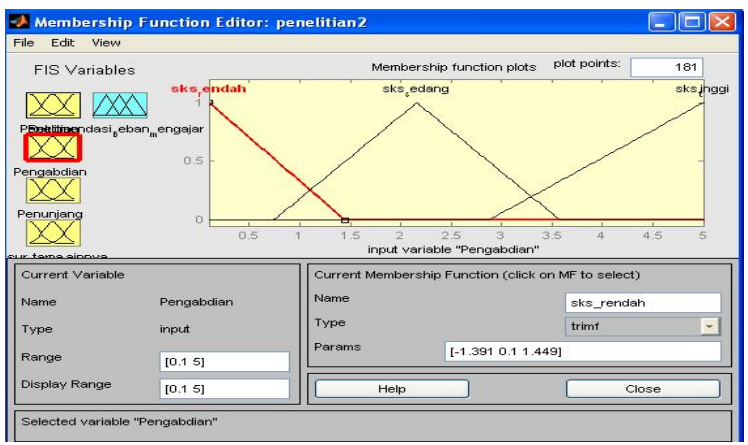

Gambar 5. Fungsi keanggotaan variabel input kegiatan pengabdian pada masyarakat

c). Kegiatan penunjang; sks unsur penunjang diperoleh oleh seorang dosen dari jabatan yang bukan merupakan kelompok jabatan ketua jurusan/ketua unit dan seterusnya sampai dengan rektor. SKS yang diberikan adalah sks dalam kegiatan unsur penunjang. Selain dari jabatan unsur penujang juga diperoleh dari kegiatan kepanitiaan, seminar-seminar dan kegiatan lainya. Untuk kegiatan kegiatan penunjang menggunakan fungsi keanggotaan segitiga, seperti yang diperlihatkan pada gambar 6 .

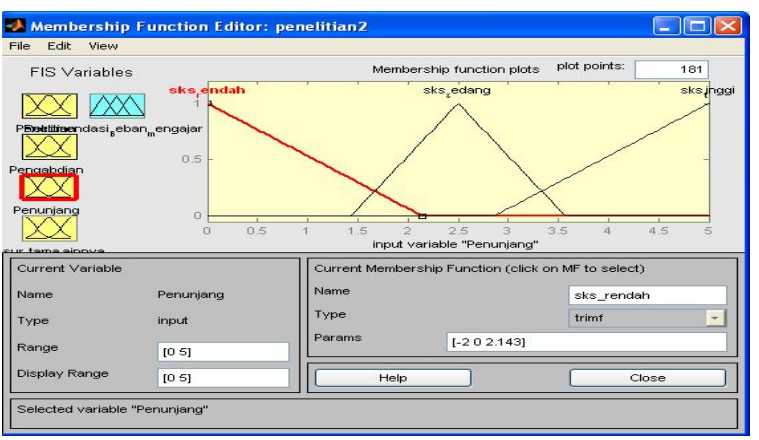

Gambar 6. Fungsi keanggotaan variabel input kegiatan penunjang

d). Kegiatan utama lainnya; sks kegiatan utama lainnya diperoleh oleh seorang dosen dari kegiatan utama selain mengajar, seperti membimbing PKL, membimbing TGA, menguji TGA dan lainnya. Untuk kegiatan kegiatan utama lainnya ini menggunakan fungsi keangotaan segitiga (Triangular membership function), seperti yang diperlihatkan gambar 7 .

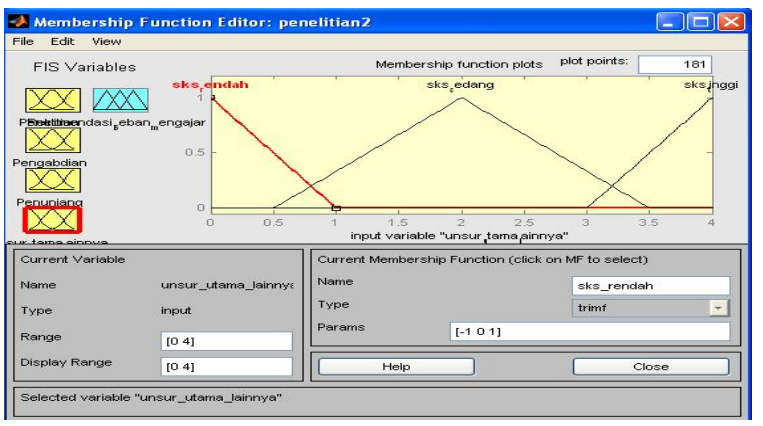

Gambar 7. Fungsi keanggotaan variabel input kegiatan utama lainnya
Keempat input ini yang akan dijadikan sebagai input Fuzzy yang akan mempengaruhi output berupa jumlah beban mengajar yang akan direkomendasikan pada seorang dosen.

\section{2 Identifikasi Variabel Output}

Variabel output sistem adalah rekomendasi beban mengajar bagi dosen yang dipilih. Beban mengajar yang direkomendasikan pada seorang dosen yang menjadi variabel keluaran sistem Fuzzy tergantung dari banyak atau sedikitnya beban dari unsur lain selain dari beban mengajar. Sks minimum dan maksimum yang diizinkan oleh DIKTI agar keberlanjutan sertifikasi dosen tetap diberikan adalah 12 sks sampai dengan 16 sks, dimana unsur pendidikan/pengajaran serta penelitian minimal 9 sks dan unsur penunjang dan pengabdian pada masyarakat minimal $3 \mathrm{sks}$.

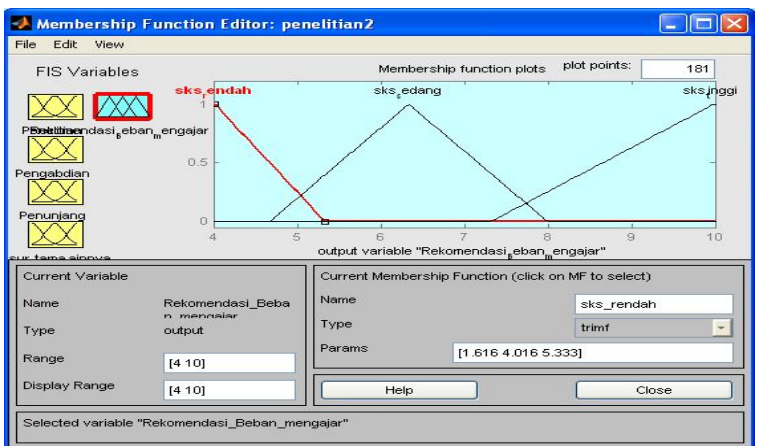

Gambar 8. Fungsi keanggotaan variabel output jumlah beban mengajar

\subsection{Proses Fuzifikasi}

Proses Fuzzifikasi adalah mengubah nilai numerik menjadi variabel lingusitik yang memiliki nilai linguistik. Untuk mendapatkan derajat keanggotaan dari nilai liguistik pada masing-masing iput sistem menggunakan fungsi keanggotaan sebagai berikut:

a. Kegiatan penelitian

Dari grafik gambar 4 persamaan fungsi keanggotaan dari kegiatan penelitian adalah:

$$
\begin{aligned}
& \text { Penelitian }_{\text {(rendah) }}= \begin{cases}0 & ; x>1,5 \\
1 & ; x=0 \\
\frac{1,5-x}{1,5} ; x \leq 1,5\end{cases} \\
& \text { Penelitian }_{\text {(sedang) }}= \begin{cases}0 & ; x<0,75 \text { dan } x>3,5 \\
\frac{x-0,75}{2,25-0,75} ; 0,75 \leq x \leq 2,25 \\
\frac{3,5-x}{3,5-2,25} ; 2,25 \leq x \leq 3,5\end{cases} \\
& \text { Penelitian }_{\text {(tinggi) }}=\left\{\begin{array}{cc}
0 & ; x<3,0 \\
\frac{x-3}{5-3} ; 3 \leq x \leq 5 \\
1 \quad & ; x=5
\end{array}\right.
\end{aligned}
$$

b. Kegiatan Pengabdian pada masyarakat

Dari grafik gambar 5 persamaan fungsi keanggotaan dari kegiatan pengabdian adalah: 


$$
\begin{aligned}
& \text { Pengabdian }_{(\text {rendah })}= \begin{cases}0 & ; x>1,5 \\
1 & ; x=0 \\
\frac{1,5-x}{1,5} ; x \leq 1,5\end{cases} \\
& \text { Pengabdian }_{(\text {sedang) }}=\left\{\begin{array}{cc}
0 & ; x<0,75 \text { dan } x>3,5 \\
\frac{x-0,75}{2,25-0,75} ; 0,75 \leq x \leq 2,25 \\
\frac{3,5-x}{3,5-2,25} ; 2,25 \leq x \leq 3,5
\end{array}\right. \\
& \text { Pengabdian }_{(\text {tinggi })}=\left\{\begin{array}{cc}
0 \quad ; x<3,0 \\
\frac{x-3}{5-3} ; 3 \leq x \leq 5 \\
1 \quad ; x=5
\end{array}\right.
\end{aligned}
$$

c. Kegiatan penunjang

Dari grafik gambar 6 persamaan fungsi keanggotaan dari kegiatan penunjang adalah:

$$
\begin{aligned}
& \text { Penunjang }_{(\text {rendah })}= \begin{cases}0 & ; x>1,5 \\
1 & ; x=0 \\
\frac{1,5-x}{1,5} ; x \leq 1,5\end{cases} \\
& \text { Penunjang }_{(\text {sedang })}= \begin{cases}0 & ; x<0,75 \text { dan } x>3,5 \\
\frac{x-0,75}{2,25-0,75} ; 0,75 \leq x \leq 2,25 \\
\frac{3,5-x}{3,5-2,25} ; 2,25 \leq x \leq 3,5\end{cases} \\
& \text { Penunjang }_{(\text {tinggi })}=\left\{\begin{array}{cc}
0 & ; x<3,0 \\
\frac{x-3}{5-3} ; 3 \leq x \leq 5 \\
1 & ; x=5
\end{array}\right.
\end{aligned}
$$

d. Kegiatan utama lainnya

Dari grafik gambar 7 persamaan fungsi keanggotaan dari kegiatan utama lainnya adalah:

$$
\begin{aligned}
& \operatorname{Utama}_{(\text {rendah })}= \begin{cases}0 & ; x>1,0 \\
1 & ; x=0 \\
\frac{1,0-x}{1,0} & ; x \leq 1,0\end{cases} \\
& \text { Utama }_{(\text {sedang) }}=\left\{\begin{array}{cc}
0 & ; x<0,5 \text { dan } x>3,0 \\
\frac{x-0,5}{2,0-0,5} ; 0,75 \leq x \leq 2,0 \\
\frac{3,5-x}{3,3-2,0} ; 2,0 \leq x \leq 3,5
\end{array}\right. \\
& \text { Utama }_{(\text {tinggi })}=\left\{\begin{array}{cc}
0 & ; x<3,0 \\
\frac{x-3}{4-3} ; 3 \leq x \leq 4 \\
1 & ; x=4
\end{array}\right.
\end{aligned}
$$

Sedangkan yang menjadi variabel output sistem Fuzzy adalah beban mengajar, dimana jumlah beban mengajar yang direkomendasikan kepada seorang dosen adalah 0 sks sampai dengan 10 sks. Fungsi keanggotaan yang digunakan untuk variabel keluaran adalah fungsi keanggotaan segitiga (Triangular membership function) dengan derajat keanggotaan sks rendah, sks sedang dan sks tinggi.

$$
\operatorname{Beban}_{(\text {rendah })}= \begin{cases}0 & ; x>5,5 \\ 1 & ; x=0 \\ \frac{5,5-x}{5,5} & ; x \leq 5,5\end{cases}
$$

$$
\begin{aligned}
& \operatorname{Beban}_{(\text {sedang })}=\left\{\begin{array}{c}
0 \quad ; x<4,5 \text { dan } x>8,0 \\
\frac{x-4,5}{6,5-4,5} ; 4,5 \leq x \leq 6,5 \\
\frac{3,5-x}{3,3-2,0} ; 2,0 \leq x \leq 3,5
\end{array}\right. \\
& \operatorname{Beban}_{(\text {tinggi })}=\left\{\begin{array}{cc}
0 \quad ; x<7,5 \\
\frac{x-7,5}{10-7,5} ; 7,5 \leq x \leq 10 \\
1 \quad ; x=10
\end{array}\right.
\end{aligned}
$$

Langkah selanjutnya adalah menentukan aturan Fuzzy, seperti yang diperlihatkan pada gambar 9. Ada 4 aturan yang digunakan dengan AND conection.

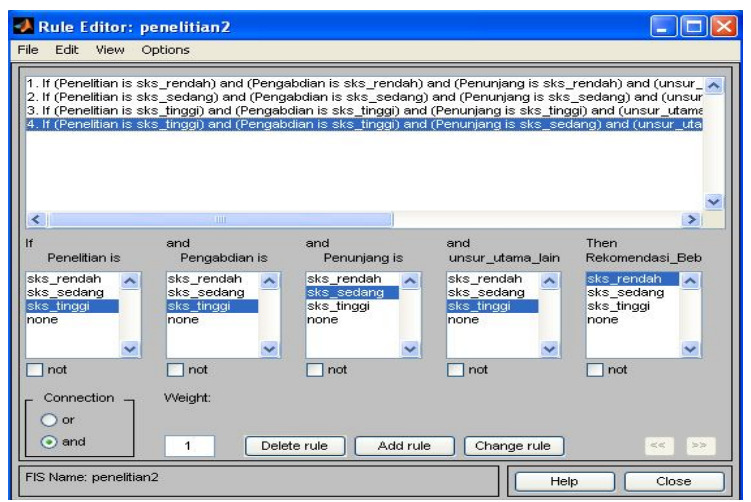

Gambar 9. Aturan Fuzzy yang Digunakan

Hasil dari rekomendasi beban mengajar diperlihatkan pada gambar 10. Sebagai contoh jika jumlah sks kegiatan penelitian 05, pengabdian pada masyarakat $=0,5$ sks, penunjang $=3$ sks, dan unsur utama lainnya $=0,5$ sks maka rekomendasi beban mengajar adalah 9 sks. Demikian seterusnya untuk mendapatkan beban mengajar yang direkomendasikan menggunakan aturan yang sudah ditetapkan.

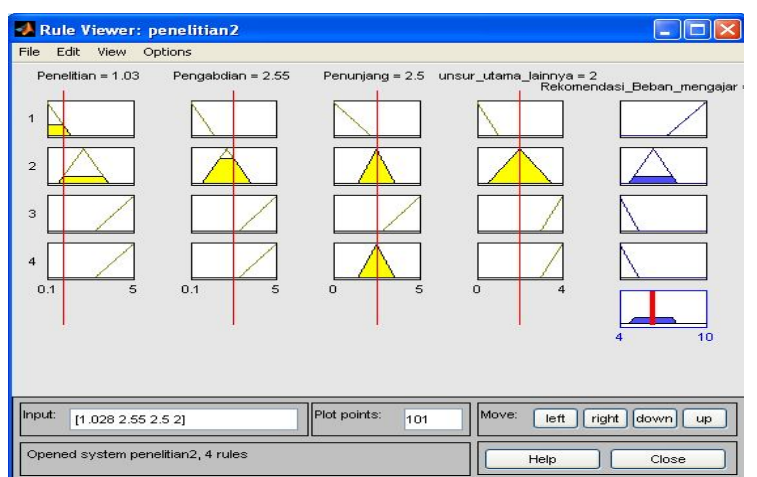

Gambar 10. Rekomendasi beban mengajar

Untuk mempermudah penggunaan dibuat aplikasi menggunakan Microsoft access 2007.

\section{KESIMPULAN}

Kesimpulan yang dapat diambil dari penelitian pembagian beban kerja dosen (BKD) untuk keberlanjutan sertifikasi dosen adalah: 
1. Perangkat lunak (software) yang dibangun dapat menentukan beban kerja dosen yaitu beban kerja dosen dengan melakukan pencarian dan pehitungan berdasarkan status dosen yaitu dosen dengan tugas tambahan (DT) dan dosen biasa (DS) dimana DS beban mengajar yang direkomendasikan 0 sks sampai dengan 13 sks, dan DT beban mengajar yang direkomendasikan 4 sks sampai dengan 6 sks.

2. Beban mengajar dosen biasa DS, dibedakan dari dosen dengan jabatan atau tidak menjabat, dimana yang dimasudkan menjabat adalah dosen yang unsur penujangnya dipenuhi secara langsung dari jabatan tersebut, dengan demikian beban mengajarnya akan berkurang dari dosen tanpa jabatan.

3. Kegiatan penelitian dan pengabdian masyarakat merupakan beban kerja wajib dan tidak boleh kosong, tetapi sks yang diperlukan kecil sehingga terhadap beban mengajar hanya sedikit berpengaruh.

4. Software ini dapat digunakan untuk membantu ketua program studi dalam membagi beban dosen yaitu beban mengajar agar keberlanjutan sertifikasi dosen tersebut tetap terjaga.

\section{DAFTAR PUSTAKA}

[1] Angga Permana, 2011, Sistem Pendukung Keputusan Dosen Berprestasi Menggunakan Metode Promethee, Skripsi, Repository UPI Bandung. tidak diterbitkan, http://repository.upi.edu/skripsiview.php?no_skr ipsi=10741 diakses tanggal 11 Juni 2012.

[2] Dadan Umar Daihani, 2001, Komputerisasi Pengambilan Keputusan. Jakarta: P.T. Elex Media Komputindo.

[3] http//www.setneg.go.id/index.php?option= com perundangan \&curr_page $=3 \&$ total_pages $=3 \&$ Ite $\underline{\text { mid }=42 \& \text { catid }=3 \& \text { tahun }=2012}$ diakses pada tanggal 15 Juni 2012

[4] Kusrini, 2007, Konsep dan Aplikasi Sistem Pendukung Keputusan. Yogyakarta : Penerbit Andi

[5] Masafumi Hagiwara, 2003, Neuro-Fuzzy-GA, cetakan ke-9. Sangyotosho.

[6] Takagi, T. and Sugeno, Kang., 1985, Fuzzy identification of systems and its applications to modeling and control. IEEE Transactions on Systems, Man and Cybernetics. 15:116-132.

[7] Turban, E., 1995. Decicion Support System And Expert System, Prentice Hall International, United State.

[8] Yuhilda. 2007. Sistem Pendukung Pengambilan Keputusan Penjadwalan Kuliah Berdasarkan Preferensi Kesediaan Waktu Dosen Untuk Mengajar (Studi kasus pada STIE SBI
Yogyakarta). Tesis tidak dipublikasikan Yogyakarta: Universitas Gadjah Mada.

[9] Zadeh, L. A., 1965, Fuzzy sets. Information and Control, 8:338-353. 
Jurnal Litek (ISSN: 1693-8097) Volume 9 Nomor 2, September 2012: hal. 124-132 